\title{
Agricultural Enterprises Human Capital Intellectualization As A Factor Providing Their Competitiveness: Theoretical Analysis
}

\author{
Petro Yukhymenko, Tetyana Sokolska, Anatoliy Danylenko, Olha Babytska, Olha Bilyk, Svitlana \\ Polishchuk, Tamara Prykhodko
}

\begin{abstract}
The role of human capital in the processes of organization of management of innovative development of agrarian enterprise and its competitiveness is considered. General characteristics and place of human capital in the management system are summarized. It is proved that human capital as one of the most important factors of innovative development of enterprises of the agrarian sector of the economy, which as a complex, systemic phenomenon requires significant changes not only in the field of technologies, but also in management and society as a whole. The basic scientific principles of investing in human capital are based on the synthesis of financial and social aspects of management. It is substantiated that for the effective realization of the existing potential of agrarian enterprises and enhancement of their competitiveness, it is necessary to create qualitative characteristics and preconditions for knowledge base management.
\end{abstract}

Keywords: human capital, social investments, intellectualization of labor, institutional factor, agrarian enterprise, competitiveness.JEL Classification: J01, J24, Q10, R23.

\section{INTRODUCTION}

Successful development of Ukraine agrarian sector enterprises, under conditions of human capital being a key factor of competitiveness, requires the search for new approaches to the process of its formation. At the same time, the latest approaches in management emphasize the creation of economic intelligence, without which the initiated processes of Ukraine's integration into the European Union will be mitigated. Therefore, an innovative approach to the formation, accumulation and efficient use of intellectual capital of enterprises in the agrarian sector of the economy is one of the priority requirements for the creation and maintenance of their competitiveness and raising the level of intellectual capitalization of human capital through constant investment in knowledge, technology and research is an urgent task for their development.

The modern theory of human capital was developed at the stage of transition to a new economy requiring new rules, new content, new dimensions and new knowledge, and

Revised Manuscript Received on July 22, 2019.

Petro Yukhymenko, Tetyana Sokolska, Anatoliy Danylenko, Olha Babytska, Olha Bilyk, Svitlana Polishchuk, Tamara Prykhodko

Bila Tserkva National Agrarian University, Ukraine allowed to determine the value of intellectualization of labor and the ways of non-material capital accumulation. This theory was developed in the papers by T. Schulz, G. Becker, J. Mincer, and others, but it is G. Becker (Becker G., 2003). the founder of this trend, who defined human capital as one of the forms of capital.

This is required by knowledge-based economy, which has completely changed the way of creating value in the enterprises (firms).

A number of foreign and Ukrainian scholars consider investment in human capital as an important investment and an effective factor of competitiveness based on intellectualization of labor and the introduction of innovations into management and production. Among the domestic scholars, who further developed certain aspects of the theory of human capital in the system of governance in their papers are S.I. Bandura, D.P. Bohunya, O. A. Grishnova, M.I. Dolishnyi, O.M. Zagurskyi, D.P. Melnychuk, AA Chukhno and others should be mentioned. This development of theoretical and methodological aspects of human capital initiated rising emergence of a new vision of an "economic person" within the framework of intellectual capital in the development of enterprises of the agrarian sector of the economy.

The aim of the study is to analyze the most important problems of forming the economic intelligence of agrarian enterprises, their ccorrelation with competitiveness and efficient development in the new business environment and to identify and substantiate directions of formation, accumulation and effective use of innovations of intellectual capital of agricultural sector enterprises in the new economy and knowledge-based management.

\section{RESEARCH METHODS}

Systemic and evolutionary approaches were applied as they require hierarchy of the essential understanding of the new public management and provide conducting the comprehensive research including identification of various characteristics, direct and feedback links and correlations that arise in the process of forming the intangible assets of an agrarian enterprise. 


\section{Agricultural Enterprises Human Capital Intellectualization As A Factor Providing Their Competitiveness: Theoretical Analysis}

\section{PRESENTATION OF THE MAIN RESEARCH MATERIAL}

Human capital is the most important factor in the competitiveness of an enterprise in a post-industrial society, where factors of production can be easily copied. The added value created in the business process arises primarily from the knowledge, abilities, skills as well as from the conditions providing their realization in the enterprise, and investment in human capital is the key factor in creating the value and achieving competitiveness in modern business.

Currently, human capital makes $64 \%$ on the planet (which is 4 times more than material one (production) (Artemenko L.B., 2016)), and in the national wealth of developed countries it makes up to $80 \%$, in some successful agricultural companies, this figure reaches $90 \%$, which proves that human knowledge and skills are crucial in a positive competitive position. In Ukraine, this figure still levels 20\%. Management of the agrarian enterprise shifts the emphasis from the servicing system to the decision-making system under establishing the entrepreneurship. The governing organization is to find the best innovative way to achieve a specific goal of enterprise development in the tough competition. The executive organization aims to protect its own management method at all costs and to protect its innovation in the general economic intelligence. Therefore, the role of human intelligence becomes crucial in the process of forming of a new management in an agrarian enterprise development. Generalization of the characteristic features of human capital and its role in the management system under modern conditions reveals that:

- manifestation of an agrarian enterprise management efficiency depends on the ability of its organizers to achieve unity in the system of economic relations of human and other types of capital (natural, material, financial), which enables their owners to receive income for the enterprise development and to engage in relations as equal partners;

- the manifestation of "human capital" in the development of the agrarian enterprise depends to a large extent on the perfection of the institutional environment, which is to ensure the manifestation of an individual, acting as an independent agent in the labor market. It correlates with his knowledge stock, health, skills and motivation that belong to an employee and are inseparable from him;

- human capital in an agrarian enterprise management system is not just a set of certain characteristics of an employee, but rather a certain stock of productive capacities created as a result of investments used effectively to obtain a result of their development in the conditions of the agricultural market variability and dynamism (Golikova N.V., 2002);

- referring the concept of "capital" with the purpose of identifying the role of the individual in the company management system indicates the need to expand the range and improve the practice of its social investment, which will result in significant and long-lasting economic effect. However, a well-known Soviet scientist S. Strumylin determined in his studies the growth of the enterprise and the national income at the expense of educational factor. Investments in "human capital" are paid in the form of highly skilled productive labor on the basis of innovative thinking, high wages and moral satisfaction a person gets from their work (Zakharova O.V., 2010). Considering this factor according to the current strategy of the EU social and economic development "Europe-2020", knowledge and innovation make the basis for human capital and the amount of financing for such purposes makes $3 \%$ of the EU total GDP, and $40 \%$ of young people must have university education. Besides, according to the Human Capital Index of the World Economic Forum, Ukraine ranked 26th among 130 countries in 2016 (The Rating Estimates of Human Capital Development, 2016).

Intellectual potential loss in rural areas is the most important problem for agricultural enterprises. The loss is caused by limited possibilities for self-realization for young people - a significant number of them can not find work in their country which results in "intellectual migration" which is especially true for rural population (Grishnov O.A.,2001; Mandybura V., 2009; Mel'nychuk D.P., 2015).

In theory, there are two forms of human capital: general (universal knowledge) and special (vocational training). The latter are important for the specific activity of the agrarian enterprise, taking into account the peculiarities of the agrarian sector development of the economy and meeting the requirements of a certain activity direction (Radionova I. 2009).

In the context of our study, the industry human capital, highlighted by O. Grishnyov (Grishnov O.A., 2001) is significant, along with the general and specific forms of human capital. Human capital correlates with the knowledge of the structure and specifics of the agrarian sector of the economy, with the development of rural areas, the agrarian enterprise, as well as with the awareness of the prospects for their development in the new economy. Indicator of this form of human capital in the industry reduces the degree of risk and uncertainty of enterprise development, reflects the power of this tool in the business.

Following I.O. Blank assertion that enterprise effective management is ensured through the implementation of a number of priority organizational principles (Blank I.A., 2001), we have defined the basic scientific principles of investing into human capital based on the synthesis of financial and social aspects of agrarian enterprise.

The principle of comprising all activities of the agrarian enterprise is closely connected with the general management principle, which consists in organizing continuous management training for management stuff and development of its human resources. The principle of integration into the general system of agrarian sector enterprises management correlates with the principle of the correspondence of the personnel management functions and the objectives of economic development of the agrarian enterprise through the organization of the effective use of human and production potential. The principle of comprising all types of management and 
activities of an agrarian enterprise can not be successfully implemented without a general management principles - the principle of consistency and the principle of investing in human capital - the complex nature of the management decisions making, which should be regarded as an integrated system that provides the development of managerial decisions, each of them directly or indirectly affects the overall performance of the enterprise development and its competitiveness. The generalized principle of ensuring high dynamism is closely connected with the principle of management implying dynamism and investment in human capital. The dynamism principle implies that the system of management of investment in human capital should timely take into account all the innovative changes in the external and internal environment of the enterprises of the agrarian sector and create conditions in which creativity and ingenuity can develop to benefit everyone. The principle of time factor accumulates the perspectives principle which is realized through the timing factor principle in the investment policy. While determining the efficiency of investment in human capital one should take into account the disunity in time of the investment in the development of personnel and obtaining economic payback. The principle of management provision is effectively implemented through the principle of economic interest and comfort of the manager. It is implemented through the principle of economic motivation to the investment results in the policy of investment in human capital - development of an effective system of moral and material incentives, decent working conditions and the provision of professional and career opportunities. The principle of ensuring the marginal efficiency of investment is combined with the general principle of management - the socioeconomic efficiency one - that is in line with the principle of investment. It involves substantiation of decisions on investing in human capital in view of its social justification and economic payback. The principle of successful management, i.e. multiple criteria of the efficiency evaluation is closely linked with the principles of scientific evaluation in management and multi-criteria assessment of investment activity in human capital. This principle should be carried out on the basis of an integrated system of quantitative and qualitative indicators and criteria.

These generalized principles are complex and cover all aspects of investing in human capital on the level of the agrarian enterprise and the agrarian sector of the economy as a whole. Considering these principles in the general business process in a modern highly competitive market at the level of the agrarian enterprise will create conditions for the maximum balance management and production organization needs in order to ensure the competitiveness of enterprises of the agrarian sector of the economy and the high efficiency of their economic activity. As the researches confirm, the principles of balancing motives and incentives as well as targeting of investing in human capital should provide such an opportunity, (Pichvarkova Z.V., 2014). At the same time, each agrarian enterprise must independently choose those principles, which, in the first place, should be based on its personnel policy and strategy of personnel development. The systematic observance of these principles will make the basis for an effective investment in the development of human capital in the agrarian sector enterprises of the economy (Tkachenko AM, Morshchenko T.S., 2008).

Despite the fact that the agrarian sector of Ukraine has a rather high level of accumulated human capital, the effectiveness of its use is low which results in the inefficient work organization. The mismatch of the workers qualification level and the workplace requirements to the level of labor productivity as well as wages which enhances the trend of "intellectual migration". Only $16.0 \%$ of agrarian high schools graduates expressed their willingness to work in rural areas. Of those who went to work now Only about $40 \%$ of the graduates work in the profession they majored in the educational institution (Conducting agrarian business in Ukraine, 2015).

Globalization processes and innovative economy development greatly reinforces the requirements for the level of professional knowledge and skills of the personnel of the agrarian enterprise of different sectors, which requires constant updating of its knowledge and improving the quality, professionalism and competence throughout all stages of the life cycle. The value of the half-life of competence over the past twenty years has decreased from 5-6 to 3 years due to the increase in the intensity of processes of knowledge obsolescence (Semykina M.V., 2007).

Currently, only $10 \%$ of agricultural enterprises managers are retrained at intervals of more than 12 years (Psacharopoulos G., Patrinos H.A., 2002). For comparison, the average period in the EU member states is about 5 years, in Japan - 1-1.5 years, which is considered to be an essential element of the success of their enterprises development and competitiveness (Imai M. Kaizen, 2005). Such attitude to intellectual capital in Ukraine has resulted in the scanty number of innovations and protected rights in the field of agricultural production as well as in lower possible incomes of agrarian enterprises.

It should be mentioned that only the really innovative economy of Ukraine, macroeconomic stability of the agrarian sector and efficient social welfare of the staff along with their intellectual property rights protection can provide the agrarian enterprise and a worker with specific human capital accumulation (Kraus N.M., 2015). At the micro level "... it should be considered on a par with the production and corporate capital" (Kirian T., Kulikov Yu., 2008) as human assets that can not be identified with the "labor value" (Chukhno A.A. Yukhymenko P.I., Leonenko P.M., 2007). Human assets, in the first place, are represented by employees' knowledge and skills (Becker G., 2003). Intellectual capital forms material and intangible components (with individual competence as their element) (Ponelo O.V., 2015).

Transformation from intellectual potential to the intellectual capital of agrarian enterprises involves the transition from the costs for human capital formation to profits from its use by transferring the value of the 


\section{Agricultural Enterprises Human Capital Intellectualization As A Factor Providing Their Competitiveness: Theoretical Analysis}

accumulated knowledge, capabilities, practical skills to the final result of the enterprise development (Mel'nychuk D.P., 2015).

Unlike the individual human capital formed by direct investment in its productive capacities development, the human capital of an agrarian enterprise requires another kind of investments - mediated, intended for mutual integration of individuals into a single territorial and social organism. This social organism will act as the bearer of the united capital of the agrarian enterprise, it forms the "social return standard" and it is one of the "elements of human potential realized in a market economy" (Psacharopoulos G., Patrinos H.A., 2002). It can be strengthened due to expansion of human capabilities and increased productivity of workers of all departments. Also, it makes people become active actors of economic growth of the potential of the agrarian enterprise, and, in turn, provides conditions for full development of a person, their educational, scientific, physical, spiritual, psychological and creative potential activation, its realization and transformation into human capital. The latter "is an integrated unity of its basic and derivative (complex) forms, reproduction of which is carried out on the basis of direct and institutional social investment in a person" (Romanovskaya E.V., Kolosova Yu.V., 2010).

The success of the agrarian enterprise, provided by the effective application of the workers knowledge, makes an existential component of their income. Public recognition of the manager as the organizer and participant in collective labor is histher achievements in real development, a kind of recognized public profit from applying knowledge as a capital (Khromov M.I., 2010). On this basis, the core of social capital (a set of real or potential resources related by a durable network of more or less institutionalized relationships of mutual relations, mutual acquaintance and recognition) - trust - is formed (Shvets' I.B., Pozdnyakova S.V., 2011).

Our study is focused on social investment which is an important tool for increasing human capital and strengthening the social cohesion of agricultural enterprises. The social cohesion is one of the competitive advantages of a certain society, which forms the safety factor and the enterprise sustainability, contributing to optimal use of the accumulated human capital. Social cohesion expresses the form of social behavior of the bearers of social responsibility for the management of the production process of the agrarian enterprise (Kirian T., Kulikov Yu., 2008) and is formed consciously, purposefully, persistently with the participation of all social forces. That is why ensuring social cohesion should be listed among the national priorities, and the program of measures in this area should become an important component of the social policy of the state and enterprises of the agrarian sector of the economy (Rusnak A.V. (red.), (2017).

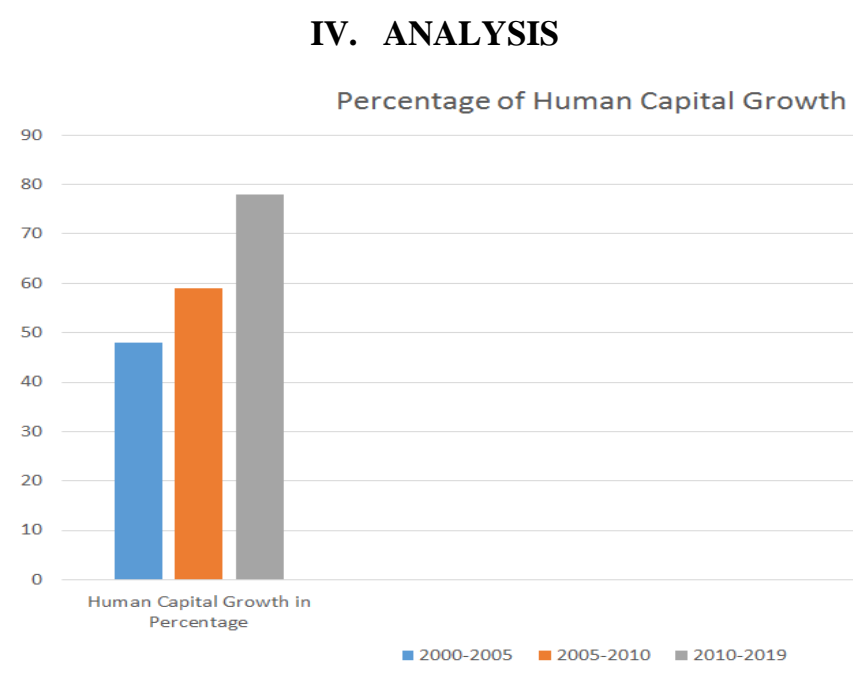

\section{Conclusions}

Modern innovative economy changes the priorities in the structure of management and development of enterprises of the agrarian sector of the economy. The intellectual property - human capital - becomes significant in its structure and substitutes the corporeal property. Under these conditions, the ability to generate innovative ideas and create opportunities for their implementation becomes vital for the agrarian enterprise management. Innovation processes do not change activities, but their technological ability through using the ability to generate new knowledge in practical activity as a direct productivity force - the main feature of the manager. Also, management system of the agrarian enterprise development, in this context, is characterized by the presence of many problems (the government's reluctance to solve the problems of agrarian enterprises labor intellectualization, the limited motivation to maximize the implementation of their human capital, etc.), which impede the effective use of their potential, and results in local people losses.

Therefore, forming of qualitative characteristics and preconditions for knowledge-based management at the state level is necessary for the effective realization of the existing potential of rural areas. Only the joint actions of the management and subordinated subsystems are able to create space for the formation of human capital by means of its intellectualization, which will provide further opportunities and competitive advantages to agrarian enterprises in realizing the strategic goals of their innovation development.

Further research in this field should ground the ways to ensure the activation of innovative development of enterprises in the agrarian sector of the economy, to encourage managers to implement innovations in economic activity.

\section{REFERENCES}

1. Artemenko L.B. (2016). Liudskyi kapital: naukovi pidkhody ta stan formuvannia v Ukraini [Human capital: scientific approaches and status of formation in Ukraine]. Galician economic bulletin (Tern.), vol. 50, no 1 , 22-31 (in Ukrainian). (in Ukrainian). 
2. Becker G. (2003). Chelovecheskoe povedenie: ekonomicheskiy podhod Izbrannyie trudyi po ekonomicheskoy teorii: [Human Behavior: An Economic Approach. Selected Works on Economic Theory]. Transl. from English by E. Batrakova, R. Kapelyushnikova, O. Shibalkina et al.; Ed. R. I. Kapelyushnikov, Pref. N. I. Levina. Moscow: Higher School of Economics, 672 (in Russian).

3. Blank I.A. (2001). Investitsionnyiy menedzhment [Investment Management]. K .: Elga-N, Nika-Center, 448 (in Ukrainian).

4. Chukhno A.A. Yukhymenko P.I., Leonenko P.M. (2007). Suchasn ekonomichni teoriyi: pidruchnyk [Modern economic theory]. K.: Znannya 878 (in Ukrainian).

5. Golikova N.V. (2002). Lyuds'kyy kapital - klyuchovyy faktor ekonomichnoho zrostannya [Human capital as a key factor in economic growth]. Innovation factor of sustainable economic growth: Coll. sciences Prospect of the Institute of Economics of the National Academy of Sciences of Ukraine. Kiev. 32-35. (in Ukrainian).

6. Grishnov O.A. (2001). Lyuds'kyy kapital: formuvannya v systemi osvity i profesiynoyi pidhotovky: monohrafiya [Human capital: formation in the system of education and vocational training:monograph]. K.: T-vo «Znannya». 254 . (in Ukrainian).

7. Imai M. Kaizen. (2005) Klyuch k uspehu yaponskih kompaniy [The Key to Japan's Competitive Success]. Transl. by Gutman. 2nd bridle (Series "Management models of leading corporations"). M.: Alpina Biznes Buks. 274 (in Russian).

8. Khromov M.I. (2010). Ekonomichnyy rozvytok v yednosti protsesiv formuvannya ta vykorystannya lyuds'koho kapitalu [Economic
[E development in the unity of processes of formation and use of human capital]. Ekonomika ta derzhava. № 1. C. 57-61. (in Ukrainian).

9. Kirian T., Kulikov Yu. (2008). Nove v teoriyi, metodolohiyi ta praktytsi lyuds'koho kapitalu. Ukrayina: aspekty pratsi [New in the theory, methodology and practice of human capital]. Ukraine: aspects of labor. № 4. 26-31. (in Ukrainian).

10. Kraus N.M.(2015). Stanovlennya innovatsiynoyi ekonomiky v umovakh instytutsional'nykh zmin: monohrafiya [The formation of the innovative economy in the context of institutional change: a monograph]. Kyyiv: TsUL, 596. (in Ukrainian).

11. Mandybura V. (2009). «Lyuds'kyy kapital»: ob"yektyvna ekonomichna real'nist' chy ideolohema? Ukrayina: aspekty pratsi ["Human capital": objective economic reality or Ideological?]. Ukraine: aspects of labor. № 2 . 26-33. (in Ukrainian).

12. Mel'nychuk D.P. (2015). Lyuds'kyy kapital: priorytety modernizatsiyi suspil'stva u konteksti polipshennya yakosti zhyttya naselennya: monohrafiya [Human capital: priorities of modernization of society in the context of improving the quality of life of the population: a monograph] Zhytomyr: Polissya. 564 (in Ukrainian).

13. Pichvarkova Z.V. (2014). Investytsiyi v lyuds'kyy kapital yak vyznachal'nyy chynnyk zabezpechennya konkurentospromozhnost natsional'noyi ekonomiky. [Investing in human capital as a determining factor in ensuring the competitiveness of the national economy]. Formation of market relations in Ukraine. № 6 (157). 229-233. (in Ukrainian).

14. Ponelo O.V.(2015). Intelektual'nyy kapital: teoretychnyy aspekt i suchasni tendentsiyi rozvytku v Ukrayini [Intellectual Capital: Theoretical Aspect and Contemporary Development Trends in Ukraine.]. Ekonomika i rehiony.. № 2(51)). C. 66-78. C. 68. (in Ukrainian).

15. Psacharopoulos G., Patrinos H.A. (2002). Returns to Investment in Education: A Further Update. Electronic resource. The World Bank, Policy Research Working Paper. September 2002. № 2881. Accessible at: http://elibrary.worldbank.org/doi/pdf/10.1596/1813-9450-2881.

16. Radionova I.(2009). Ekonomichne zrostannya $\mathrm{z}$ uchastyu lyuds'koho kapitalu [Economic growth with the participation of human capital]. Economy of Ukraine. 2009. № 1. C. 19-30. (in Ukrainian).

17. Reytynhovi otsinky rozvytku lyuds'koho kapitalu 2016: Ekonomichnyy dyskusiynyy klub [Rating Estimates of Human Capital Development 2016: Economic Discussion Club]. Retrieved from: http://edclub.com.ua/analityka/reytyngovi-ocinky-rozvytku-lyudskogo-ka pitalu-2016. (in Ukrainian)

18. Romanovskaya E.V., Kolosova Yu.V. (2010). Znachenie sotsialnogo i chelovecheskogo kapitala [The value of social and human capital]. Retrieved from: http://www.be5.biz/ekonomika1/r2010/01732.htm. (in Russian).

19. Rusnak A.V. (red.) (2017). Stratehichni napryamy sotsial'no-ekonomichnoho rozvytku ahrarnoho sektoru ekonomiky Ukrayiny: kolektyvna monohrafiya [Strategic directions of socio-economic development of the agrarian sector of the Ukrainian economy: a collective monograph]. Kherson: TOV «VKF «STAR» LTD» 432 (in Ukrainian).

20. Shvets' I.B., Pozdnyakova S.V. (2011). Otsinka nahromadzhennya lyuds'koho kapitalu na promyslovykh pidpryyemstvakh [Estimation of accumulation of human capital at industrial enterprises]. Donets'k: Nord-Press. 172 c. (in Ukrainian).

21. Semykina M.V. (2007). Yakist' znan' vitchyznyanykh kadriv v konteksti vzayemodiyi navchal'nykh zakladiv i biznesu [ The quality of knowledge of domestic staff in the context of interaction between educational institutions and business]. Labor Market and Education: K.: Takson, 144-147 (in Ukrainian).

22. Tkachenko AM, Morshchenko T.S. (2008). Stratehichni napryamy udoskonalennya upravlinnya personalom: monohrafiya [Strategic directions of improvement of human resource management: monograph]. Zaporizhzhya: Vyd-vo Zaporiz'koyi derzh. inzhener. akad. 233 c. (C. 127). (in Ukrainian).

23. Vedennya ahrarnoho biznesu v Ukrayini 2015 [Conducting agrarian business in Ukraine 2015]. Retrieved from: http://ucab.ua/files/Survey/Doing/Doing_2015_ukr_web.pdf. (in Ukrainian).

24. Zakharova O.V. (2010). Upravlinnya investuvannyam u lyuds'kyy kapital: metodolohiya, otsinka, planuvannya: monohrafiya. [Management of investment in human capital: methodology, assessment, planning: monograph] Donets'k: «DVNZ DonNTU», 378 (in Ukrainian). 